\title{
Iron, Manganese, Ash, and Nitrogen in some Plants from Salt Marsh and Shingle Habitats
}

\author{
BY \\ A. V. GORHAM \\ AND \\ E. GORHAM \\ (Botany Department, University College, London)
}

\begin{abstract}
Analyses for iron, manganese, ash, and nitrogen are recorded for some plants from salt marshes and shingle hooks. Ash is much higher, and iron and manganese are much lower, than in plants from underwater lake muds, woodland soils of varying humus content and acidity, and semi-aquatic marsh, fen, and bog soils. Since both lake muds and salt-marsh soils are deficient in oxygen, with iron and manganese presumably mobile as divalent ions, the difference in concentration of the two elements in plants from the two types of habitat requires explanation. It is suggested that the much greater total ion concentration of the salt-marsh soil solution may depress iron and manganese assimilation through ionic antagonism:
\end{abstract}

\section{INTRODUCTION}

T $\mathrm{N}$ an earlier paper (Mayer and Gorham, 195r) submerged freshwater plants were shown to accumulate much larger quantities of iron and manganese than most plants in semi-aquatic and woodland habitats. It was suggested that the anaerobic and strongly reducing conditions in the lake muds were responsible for these high plant levels of iron and manganese, by maintaining the two elements in their reduced and more soluble divalent state. Since salt-marsh soils may also be largely anaerobic, and salt-marsh plants are known to have a high mineral content, it seemed worth while to investigate the amounts of iron and manganese in such species. Therefore, in the latter part of August 1952, twelve samples of six characteristic species were collected for this purpose on the younger salt marshes at Blakeney Point in Norfolk. For comparison, three species were collected from shingle hooks in the same locality. The earlier plant samples were analysed for total ash and nitrogen as well as the metals; these determinations were also made on the present series.

\section{The AREA}

The general ecology of Blakeney Point is discussed in detail by Tansley (1939), who has summarized the extensive studies of Oliver and his collaborators (cf. also Oliver, r9I3; Oliver and Salisbury, I9I3). Salisbury (1922) has analysed the surface soils of the area for $\mathrm{pH}$, ignition loss, and calcium carbonate. The shingle soils are circumneutral, those of the salt marshes are slightly alkaline. The organic contents (as ignition loss) of both groups 
average between 5 and to per cent. dry weight. Their levels of calcium carbonate are usually very low, the averages for the general areas examined in this study being 0.1 per cent. dry weight for the shingle soils and 2.6 per cent. for those of the salt marshes.

The profile morphology of Blakeney Point salt-marsh soils has also been investigated; in conjunction with measurements of redox potential, tests for ferrous and ferric iron, and for sulphides (E. Gorham, in preparation). These studies indicate that the extremely imperyious muds of the main marshes are largely depleted of oxygen within the rooting depths of the vegetation. Iron and manganese must be rather freely mobile in such soils, to allow the extensive accumulations of black ferrous sulphide observed where organic decay has brought about extremely reducing conditions; or to account for the rusty precipitations of ferric hydroxide where air or aerated water has been introduced into the predominantly anaerobic soil. Such oxidizing conditions are chiefly encountered along well-drained creek margins, around long decayed root channels or worm tracks, and in more permeable sand layers which are often found a short distance beneath the muds. The sandier soils of the marsh margins are also well aerated.

\section{Methods}

Whole-plant tops were sampled from typical habitats during August 1952 and were immediately water-washed very carefully. Their glossy surfaces made cleaning relatively easy and efficient. The material was then dried in an improvised oven at $70-90^{\circ} \mathrm{C}$. Before analysis the plants were again dried, at $105-110^{\circ} \mathrm{C}$.

Ash. The total mineral matter was determined by ignition at about $700^{\circ} \mathrm{C}$., since a lower temperature did not dispose of all the carbon.

Nitrogen. This constituent was estimated by the usual micro-Kjeldahl method, on duplicate samples.

Iron. The dry plant material was digested with a mixture of nitric, perchloric, and sulphuric acids (Sandell, 1944, p. 278) and diluted to volume. Iron was then estimated on an aliquot by the thiocyanate method in $5^{\circ}$ per cent. acetone, hydrogen peroxide being added as oxidizing agent and ethylene glycol monobutyl ether for colour stability (Snell and Snell, 1949, vol. 2, p. $3^{10}$ ). A photocolorimeter with blue filter was used for the colour comparison. Duplicate samples were tested.

Manganese. Another aliquot digested as above was boiled with added sulphuric and phosphoric acids and potassium periodate (Sandell, 1944, p. 314), after which colour was read with a green filter. Again duplicate samples were tested.

\section{RESULTS}

The analyses for both shingle and salt-marsh plants are given in Table I. Iron and manganese are expressed as milligrammes per hundred grammes dry weight, ash, and nitrogen as per cent. dry weight. 
TABLE I

Iron, Manganese, Ash, and Nitrogen in Shingle and Salt

Species.

Honckenya péploides

Silene maritima

Limonium binervosum

Limonium vulgare.

Limonium humile

Aster tripolium (leaves)

Aster tripolium $\left\{\begin{array}{l}\text { (leaves) } \\ \text { (stems with flower buds). }\end{array}\right.$

Pelvetia canaliculata

Salicomia perennis .

Salicornia stricta

Salicomia stricta

Salicomia stricta

Salicornia stricta

Salicormia stricta

Salicornia stricta

\begin{tabular}{|c|c|c|c|c|}
\hline Iron & Manganese & $\mathrm{Fe} / \mathrm{Mn}_{\mathrm{n}}$ & Ash & Ni \\
\hline
\end{tabular}

7

2

4

2

4

2

6

I

I I

5

2

4

I

3

3

2

5

2

I

4

6
39

17

13

9

20

I 5

38

42

25

19

$3^{8}$

44

44

41

45

42
Site descriptions

Sandy shingle, well aerated.

Sandy shingle, well aerated.

Sandy shingle, well aerated.

Aster-Salicornia marsh; mud largely anaerobic.

Aster-Salicornia marsh; mud largely anaerobic.

Salicornia-Pelvetia marsh; mud largely anaerobic.

Aster-Salicornia marsh; mud largely anaerobic.

Salicornia-Pelvetia marsh, free-floatin in shallow pan.

Margin of marsh, with Halimione portulacoides and Suaeda fruticosa; muddy sand well aerated.

Edge of creek, with Halimione and Suaeda maritima; sand well aerated.

Well-drained high-level marsh, with Halimione and Suaeda maritima; sandy mud well aerated.

Edge of shingle bank, few plants; thin mud layer well aerated.

Salicornia-Pelvetia marsh; mud largely anaerobic, inside edge of pan.

Salicornia-Pelvetia marsh; mud largely anaerobic.

Aster-Salicornia marsh; mud largely anaerobic. 


\section{Gorham and Gorham-Iron, Manganese, Ash, and Nitrogen}

Iron. The values for this constituent range from 2 to $22 \mathrm{mg}$./100 g: dry wt. The lowest amount is that in the Aster flowering stems. The three Limonium species, including one from shingle and two from salt marshes, average more than twice the iron contents of the other plants. There seems to be little difference in iron level between plants of aerobic and anaerobic soils.

Manganese. The maximum concentration of this element is $7 \mathrm{mg} / \mathrm{ro0} \mathrm{g}$. dry wt., in Silene maritima. Two samples of Salicornia stricta contain as little as $\mathrm{r} \mathrm{mg}$./ $\mathrm{ro0}$ g. dry wt. Again, there appears little difference in plants of oxidizing or largely reducing soils.

$A s h$. Total mineral matter is generally higher in the salt marsh species than in those of the shingle, with Salicornia and Aster containing about 40 per cent. of ash. Within the two types of habitat the genus Limonium provides the lowest figures. There is little variation in ash content of Salicornia stricta, whether on aerobic or anaerobic soils.

Nitrogen. As might be expected, the flowering stems of Aster exhibit the smallest nitrogen concentration, 0.6 per cent. dry wt. The highest value, 2.9 per cent., comes from Silene maritima. Plants of shingle and salt marsh, or aerobic and largely anaerobic salt marsh, apparently differ little in this respect. Salicornia stricta shows considerable variability in nitrogen level, ranging from $I \cdot 3$ to $2 \cdot 6$ per cent. dry weight.

\section{Discussion}

The main interest of the present results lies in a comparison with data from other types of habitat. In view of the extreme variation and skewed distribution of iron and manganese concentrations in the plants examined earlier (Mayer and Gorham, I95I), such a comparison is probably best made from median values for each habitat type. Table II provides such a series of very

TABLE II

Nitrogen, Ash, Iron, and Manganese (approximate median values) in Plants from Various Natural Habitats

\begin{tabular}{|c|c|c|c|c|c|c|}
\hline \multirow[b]{2}{*}{ Habitat. } & \multirow[b]{2}{*}{ Soil pH. } & & & Iron & Manganese & \multirow[b]{2}{*}{$\mathrm{Fe} / \mathrm{Mn}$. } \\
\hline & & $\underbrace{\text { Nitrogen }}_{\% \text { dry }}$ & $\frac{\text { Ash }}{\text { ight. }}$ & \multicolumn{2}{|c|}{$\begin{array}{l}\text { mg. per 100 g. } \\
\text { dry weight. }\end{array}$} & \\
\hline $\begin{array}{l}\text { Salt marsh } \\
\text { Lake mud }\end{array}$ & $\quad>77$ & $\begin{array}{l}1 \cdot 7 \\
3 \cdot 7\end{array}$ & $\begin{array}{l}41 \\
18\end{array}$ & $\begin{array}{r}7 \\
106\end{array}$ & $\begin{array}{r}3 \\
76\end{array}$ & $\begin{array}{l}2 \cdot 6 \\
x \cdot 0\end{array}$ \\
\hline Marsh and fen & . $4 \cdot 6-7 \cdot 3$ & $2 \cdot 2$ & 6 & 25 & 35 & 0.7 \\
\hline Fen and bog & . $\quad 2 \cdot 9-4.5$ & $1 \cdot 8$ & 4 & 19 & 55 & 0.3 \\
\hline Woodland. & $.4 \cdot 6-7 \cdot 6$ & $2 \cdot 3$ & 9 & 26 & 23 & $I \cdot I$ \\
\hline Woodland. & . $2.5-4.5$ & $2 \cdot 1$ & 6 & 24 & 44 & 0.6 \\
\hline
\end{tabular}

approximate medians, obtained by fitting cumulative frequency distributions for element concentrations roughly by eye, and intersecting at the 50 per cent. level. While these medians are only rather crude approximations, it is believed that the differences between habitat types are of sufficient magnitude to make serious errors in the order of values unlikely. 
It appears from Table II that salt-marsh plants contain much less iron and manganese than plants from other habitats, especially those growing on reducing lake muds, which are high in both elements. This is true even on other than dry weight comparisons. For instance, if iron and manganese are calculated per unit of total mineral ash, or per unit of total nitrogen, the saltmarsh plants are still very low. (The underwater plants also remain highest in iron; but because of low ash and nitrogen contents the plants of acid fens and bogs become highest in manganese on these bases.). A major problem

TABLE III

The Acidity of Freshly Ground Tops from Plants of Shingle, Salt Marshes, and Freshwater Lakes

Distilled water added, $\%$ of fresh $\mathrm{pH}$ glass

Species. tissue weight. electrode.

Lake plants:

Nitella

100

$6 \cdot 36$

Sparganium minimum

100

$6 \cdot 28$

Potamogeton alpinus

100

100

100

Elodea canadensis

Littorella uniflora

Nuphar lutea

100

200

Isoetes lacustris.

100

$6 \cdot 28$

$6 \cdot 16$

$6 \cdot 10$

5.04

4.92

$4 \cdot 44$

Salt marsh plants:

Pelvetia canaliculata .

50

$7 \cdot 96$

Suaeda maritima

0

Limonium humile

L. vulgare

50

Aster tripolium.

50

Salicornia stricta (lower marsh) .

$S$. stricta (upper marsh)

0

o

$\circ$

$6 \cdot 47$

6.00

$5 \cdot 96$

$5 \cdot 91$

$5 \cdot 90$

$5 \cdot 84$

Şhingle plants:

Honckenya peploides . . . . 25

Senecio jacobiea.

25
25

here is why salt-marsh plants, with a high mineral uptake and growing on reducing muds where iron and manganese must be rather mobile, should be so low in these elements, especially when plants on similarly reducing lake muds are so high.

It was considered that the acidity of plant sap might differ in the two habitats, thus affecting the movement of iron and manganese within the plant tissues. An attempt was made to assess this factor by grinding fresh tops, usually. with the addition of some distilled water, and measuring the $\mathrm{pH}$ of the product. The results, given in Table III, suggest that this factor is unlikely to be decisive, although the crudity of the technique does not allow certainty on this point.

It also seemed possible that air might diffuse more easily into the periodic- 
ally exposed salt-marsh soils than into the permanently waterlogged lake muds, so that iron and manganese would be precipitated before reaching the root surfaces of the salt-marsh plants. However, while rusty precipitations may be observed around their roots, these are far from universal. Very many roots show little or no trace of ferric hydroxide, while others exhibit rusty sheaths over widely varying proportions of their length. Sometimes, it is true, new roots grow along old rusty root channels, where the ferrous sulphide deposited during intense decomposition has later been oxidized, upon the entry of air once the organic matter has mostly decayed away. None the less, the surface soils of the main salt marshes are in general highly impervious, and probably remain anaerobic to within a few millimetres of the top, even during the longer periods of exposure. In connexion with aeration, some of the analysed species from both lake muds and salt marshes possess well-developed root aerenchyma or air spaces.

A factor which may well be of great importance is the far higher total ion concentration of the salt-marsh soil solution. Ferrous and manganous ions will be of far less importance in the salt marsh than in the much more dilute soil solution of the lake muds, i.e. they will form a much smaller fraction of the total ions presented to the root surfaces. Thus these elements should account for a much smaller proportion of the total mineral uptake of the saltmarsh species. And in fact, as a percentage of ash, the median iron content of underwater lake plants is more than 25 times that of salt marsh species, while the median manganese value is more than 50 times as great.

The importance of ion antagonism for plant growth and nutrient uptake has been stressed by Olsen (I942, I950, I953). There seems little reason to loubt that it will have a profound influence upon the accumulation of iron and manganese.

The ratio of iron to manganese is also a matter of interest, since it varies widely in different habitats. The median values in Table II decline with increasing acidity of the soil. In the case of plants on woodland and semiaquatic soils in the Lake District, this is clearly due to a distinct increase of manganese in the more acid sites, iron remaining much the same. Moreover, $\mathrm{Fe} / \mathrm{Mn}$ ratios are lower in plants of semi-aquatic soils than in comparable woodland sites-again largely because manganese is higher. It is interesting that in spite of great divergence in absolute levels, the $\mathrm{Fe} / \mathrm{Mn}$ ratios of plants on circum-neutral lake muds and slightly alkaline salt-marsh soils follow the general trend in relation to soil $\mathrm{pH}$.

To turn to total mineral content, the salt-marsh species are remarkable in yielding up to 45 per cent. of ash. The maximum value recorded for the other habitats was $2 \mathrm{I}$ per cent. in Littorella growing on lake mud. This high level of mineral matter in the salt-marsh plants is responsible for making them appear the lowest in nitrogen on the dry weight basis. If nitrogen is recalculated per unit of combustible organic material, it then becomes slightly higher in the salt-marsh species than in those from woodland and semiaquatic soils. However, on this basis the submerged lake plants contain almost 
twice as much nitrogen as the other plants, which may of course reflect a lower proportion of carbonaceous supporting tissues in the former.

\section{ACKNOWLEDGEMENTS}

We should like to thank Dr. M. Y. Stant, Miss B. Stephen, and Mr. Than Tun for advice and technical assistance.

\section{Literature Cited}

Mayer, A. M., and Gorham, E., I95 I : The Iron and Manganese Content of Plants present in the Natural Vegetation of the English Lake District. Ann. Bot., N.s., xv. 247-63.

Oliver, F. W., 1913: Some Remarks on Blakeney. Point, Norfolk. Journ. Ecol., i. 4-15.

- and Salisbury, E. J., I913: Topography and Vegetation of Blakeney Point, Norfolk. Trans. Norfolk Norw. Nat. Soc., ix.

Olsen, C., 1942: Water Culture Experiments with Higher Green Plants in Nutrient Solutions having Different Concentrations of Calcium. Compt. Rend. Trav. Lab. Carlsberg, xxiv. 69-97.

- 1950: The Significance of Concentration for the Rate of Ion Absorption by Higher Plants in Water Culture. Ibid., xxvii. 29r-3o6.

1953: The Significance of Concentration for the Rate of Ion Absorption by Higher Plants in Water Culture. I $\checkmark$. The Influence of Hydrogen Ion Concentration. Physiol. Plant., vi. 848-58.

SAlisbury, E. J., 1922: The Soils of Blakeney Point: A Study of Soil Reaction and Succession in Relation to the Plant Covering. Ann. Bot., xxxvi. 391-43r.

SANDELl, E. B., 1944: Colorimetric Determination of Traces of Metals, Ist edition. New York.

SNELl, F. D., and SNell, C. T., 1949: Colorimetric Methods of Analysis, vol. 2, 3rd edition. New York.

Tansley, A. G., 1939: The British Islands and their Vegetation. Cambridge University Press. 